\title{
More lawyers, more litigation? Exploring trends in litigation and the legal profession in Ontario, Canada
}

OÑATI SOCIO-LegAL SERIES VOlume 11, Issue 2 (2021), 535-556: “TOO MuCh Litigation?”: FACTS, REASONS, CONSEQUENCES, AND SOLUTIONS

DOI LINK: HTTPS://DOI.ORG/10.35295/OSLS.IISL/0000-0000-0000-1118

RECEIVED 03 SEPTEMBER 2019, ACCEPTED 10 JANUARY 2020

\section{AVNER LEVIN*}

ASHER ALKOBY*

\section{Abstract}

This brief paper explores the correlation and potential relationship between the composition of the legal profession and trends in litigation, in Ontario, Canada. Specifically, we ask whether there is a positive correlation between the numbers of lawyers and paralegals licensed to practice in the province, and the amount of civil litigation initiated across the province. The paper then discusses possible reasons for the trends in the profession and in litigation, and considers traditional objections, such as the argument that an increase in the number of lawyers will lead to "litigation explosion". The paper concludes with suggestions for future research in this area.

\section{Key words}

Litigation trends; access to justice; Ontario; Canada; legal profession

\section{Resumen}

Este breve artículo se adentra en la correlación y posible nexo entre la composición de la profesión jurídica y las tendencias en demandas en Ontario, Canadá. Concretamente, nos preguntamos si existe correlación positiva entre el número de abogados y profesionales parajudiciales con licencia en ejercicio, y el número de litigios civiles iniciados. Después, el artículo comenta posibles razones de las tendencias en la profesión y en las demandas, y toma en consideración objeciones que tradicionalmente

\footnotetext{
This research has been supported by a grant from the Law Foundation of Ontario. The authors would like to thank Gavin Wiggins and Erica Wright for their invaluable assistance, and participants of the CALSB 2019 annual conference and participants of the "Too Much Litigation?" Oñati 2019 workshop, and in particular, Sally Gunz, Shelley McGill, Phil Nichols and Bill Haltom for their comments.

* Department of Law and Business, Ted Rogers School of Management, Ryerson University, 350 Victoria Street Toronto, Ontario, M5B 2K3 Canada. Email address: avner.levin@ryerson.ca

* Department of Law and Business, Ted Rogers School of Management, Ryerson University, 350 Victoria Street Toronto, Ontario, M5B 2K3 Canada. Email address: aalkoby@ryerson.ca
} 
se han hecho, como que el aumento en el número de abogados conducirá a una "explosión de demandas". Concluimos con sugerencias para investigaciones futuras.

Palabras clave

Tendencias en litigios; acceso a la justicia; Ontario; Canadá; profesión jurídica 


\section{Table of contents}

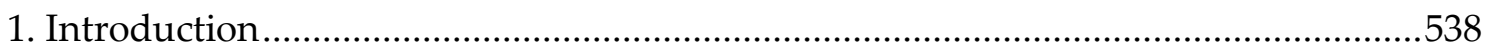

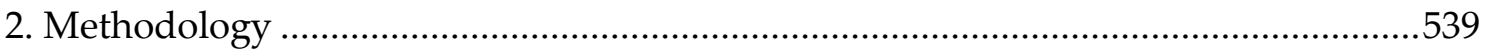

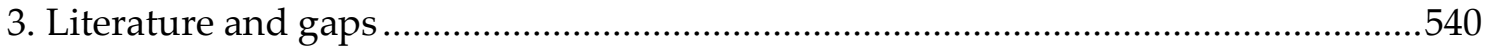

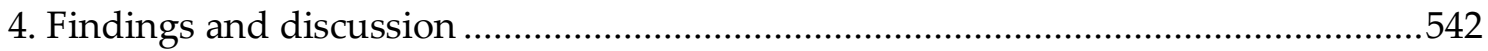

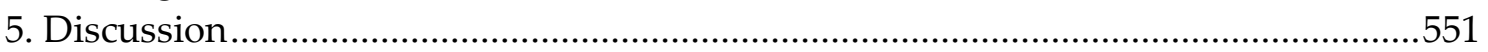

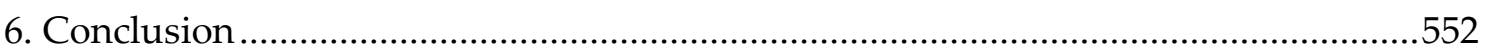

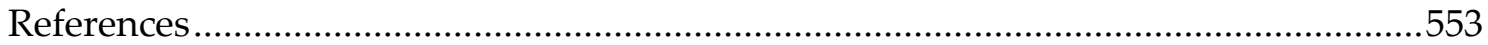




\section{Introduction}

There has been widespread discussion and speculation about the correlation and relationship that exists, if at all, between the composition of the legal profession and litigation trends. For example, there has been dated yet wide-reaching discussion about the negative societal and professional impact of too many people entering the legal profession, in Canada and other countries. Concerns have been expressed by academics and professionals that the admission of too many lawyers to the Bar will, among other things, result in a supply-driven excess in litigation (Easton 1997, Andrew et al. 1999). These concerns were mostly based on speculation, as there is no empirical data that explicitly compares the amount of litigation in Canada to the number of lawyers. Similarly, there has been speculation in Ontario that the introduction of increasing number of paralegals, and the approval of new areas of practice such as Family Law (Law Society of Upper Canada - LSO - 2017) has led and will lead to increased litigation in areas for which paralegals are licenced. On a more positive note, hopes have been expressed that opening the legal and paralegal profession to more entrants would result in greater access to justice and that the legal representation of individuals and corporations in Ontario would become more efficient and effective. Among others, we had hoped that one outcome of an increased number of legal professionals would be a more diverse and inclusive profession that is representative of contemporary Ontarian society in terms of gender, age and other identity markers.

We are now in a position to address the correlation question by comparing datasets that have been largely disparate to-date, and this paper is the first in a number of inquiries that we will conduct into the relationship between the composition of the profession and litigation trends. The Law Society of Ontario has been releasing increasingly detailed information on the composition of the profession, from as early as the mid 1980s. In addition, richer information about litigation, including the numbers and causes of action filed, is now available through Statistics Canada (Statistics Canada 2018) and through innovative analysis of practice management information, published by practice management vendors and other analysts. The purpose of this paper is to start making sense of these data and fill existing empirical gaps through an analysis and comparison of the data available specifically for the number of lawyers and the number of paralegals in Ontario to trends in the number and types of civil lawsuits filed in court. ${ }^{1}$ This in turn will allow us to determine more conclusively whether the introduction of more lawyers and paralegals into the profession has resulted in more civil litigation as has been feared by some, and hoped by others, and to determine how future research would best provide the empirical information that will help improve access to the justice system in Ontario.

The structure of this paper is as follows. We begin with a discussion of our data sets and methodology and a review of existing literature. We then present and discuss the comparison of the data regarding the legal profession with the data on litigation in Ontario. Finally, we suggest some conclusions and insights for future research in this area.

\footnotetext{
${ }^{1}$ We note here that litigation data captures, by definition, disputes between parties that have advanced to a stage in which a record about the dispute has been created. There are in all probability many more disputes that do not advance to such a stage, for a myriad of reasons, some of which may impact litigation trends as well.
} 


\section{Methodology}

We used a quantitative longitudinal approach in this paper in which data from several secondary sources were statistically analyzed to determine potential correlations between the sets. It is of course not possible to determine causation on the basis of such comparisons, and indeed, in the following sections we discuss several potential reasons for the patterns that we observed. In this respect, comparison with similar research projects in other jurisdictions would be helpful. At the same time, we note where there appears to be an empirical basis on which specific speculations, such as the prediction of a potential "litigation explosion," or a crisis of rising lawsuits in Canada (The Ottawa Citizen 1996, Olson 1997, Gonzalez 2006) can be contested.

The data sources and sets in use for this paper were as follows and briefly described immediately below:
a. Statistics Canada
b. The Law Society of Ontario (formerly the Law Society of Upper Canada)
c. The Ministry of the Attorney General of Ontario

\section{a. Statistics Canada}

In 2005 Statistics Canada began collecting and analyzing civil litigation data across Canada. The data are available by jurisdiction (provincial, federal) and by cause of action. Statistics Canada collects the data directly from the respective courts, and publishes the data on an annual basis. The causes of action collected by Statistics Canada are bankruptcy proceedings, debt collection, "other" contractual matters (such as landlord/tenant disputes, employment issues, mortgages and liens), motor vehicle tort litigation, "other" tort litigation (such as defamation and negligence), probate actions and two more general categories of "other" civil action (such administrative law issues, constitutional issues and any issue that does not fit the above categories) and "unknown" type of action (where there is insufficient information collected by the courts). Family law litigation is not presently collected and is not included in the data.

\section{b. The Law Society of Ontario}

The Law Society (LSO) publishes annual reports, that since the early 1980s have included some information about the state and composition of the legal profession. Data have included membership numbers per licensing fee categories, and increasingly in recent years, demographics and diversity information, such as gender or identification as a member of a racialized group. The LSO has also published information about areas of practice and the amount of time members devote to each area. Since 2008 the information has also included paralegals, which in Ontario are also regulated by the LSO. All data are reported by members to the LSO, and some diversity-related information is voluntary.

\section{c. The Ministry of the Attorney General of Ontario}

Prior to the beginning of the collection of information by Statistics Canada in 2005 various provinces, including Ontario, engaged in their own collection efforts. In Ontario, information was collected at a local court level and then aggregated by the Ministry of 
the Attorney General (MAG). The information was published annually as Court Statistics Annual Reports as early as the beginning of the 1970s. ${ }^{2}$ Unfortunately, the categories and methodology used by Ontario to collect the information published in these reports were not adopted by Statistics Canada. It was therefore not possible to immediately compare litigation data prior to 2005 with litigation data post 2005. In fact, so far we have only been able to compare the total number of cases that have been initiated, and in order to do so we have removed from the old reports all family law and criminal law related proceedings, since these categories are excluded by Statistics Canada from their reports.

Following our discussion of the literature we present the analysis that we have been able to conduct so far on these datasets and our comparison of the number of civil lawsuits filed annually in the Ontario Provincial and Superior courts (categorized by type of claim where data exist) to the number of lawyers practicing in Ontario and their area of practice (again, where data exist). For more recent years, we are able to include paralegals in the analysis as well. Finally, as noted above, although a more complete analysis of litigation trends should include data on family disputes and criminal law, this information is not presently available from Statistics Canada.

\section{Literature and gaps}

During the 1980s and 1990s, in part attributed to tort reform in the US, there was palpable public anxiety over a claimed increase in litigation (Galanter 1986, Alexander 1994). Concerns about this trend spreading to Canada were voiced, fear of excessive litigation and, concurrently, of too many lawyers competing in an oversaturated market (The Ottawa Citizen 1996, Harnick 1997). There was concern of "supply-driven" litigation, due to the fact that an over-competitive market would make lawyers more eager to solicit clients, placing strain on the courts, and creating more opportunity for ethical misconduct (Easton 1997, Andrew et al. 1999). Similar concerns have been voiced in Israel, where the profession has undergone over the last two decades a process of expansion and deregulation, leading to recent claims of being the jurisdiction with most lawyers per capita in the world (Katvan 2013). Some have argued that the motivation of such concerns is to be found in attempts to maintain the elevated societal status of the profession (Abel 1988, Ziv 2008) or to maintain the gender and ethnic homogeneity of the legal profession (Katvan 2013), rather than legitimate fears of an overly litigious society.

There have been several attempts in other jurisdictions to examine whether an increase in the size of the profession is correlated with an increase in litigation. In Europe, for example, a recent study analyzed thirty member states of the European Council between 2006-2014, finding that the number of lawyers had a positive and statistically significant impact on litigation rates (Bielenand and Marneffe 2018). Scholars have been careful to note, though, the influence of other factors on the decision to litigate. In the United States, for example, one study examined tort filings in ten representative states over twenty years, looking at factors that influenced the decision to litigate (Yates et al. 2001). One important finding was that the rate of litigation was higher in states with fewer

\footnotetext{
${ }^{2}$ Many thanks to Bert Kritzer for making these reports available to us and allowing us to contact MAG staff that had assisted him in the past.
} 
welfare programs (Yates et al. 2001). This may indicate that other factors (beyond the increase in size of the legal profession), such as the political leaning of governments, their social policy decisions, as well as the judicial appointment process and court administration influence the decision to litigate, and that claims that the size of the legal profession directly impacts the amount of litigation may be too simplistic (Yates et al. 2001, 2010).

Indeed, recent scholarly concerns about litigation have been not over its increase, but that it may be diminishing, with an apparent decline observed in both civil and criminal litigation in the United States (Galanter 2004, Burns 2013, Scallen 2017). This trend is occurring internationally as well, with scholars in Germany, Japan, the Netherlands and the United Kingdom all noting a decrease in litigation (Chan 2019, de Groot-van Leeuwen 2019, Schultz 2019, Seidman 2021, Bocharov 2021). ${ }^{3}$ In the United States the discussion of vanishing litigation has largely focused on tort law and the implications of tort reform on the litigation rate and access to justice (Galanter 1996, Solomon 2014, Daniel and Martin 2016). Notably, tort reform was enacted in response to decades of criticism of the American civil justice system by corporations and special interest groups, citing the same rhetoric of a litigation explosion and "out of control" juries (Nockleby 2007). One study, based on a methodology of surveys and interviews with practitioners in Texas, found that tort litigation in that state declined significantly following tort reform, and that lawyers took on fewer cases, screened potential plaintiffs more strictly, and altogether left this area of practice (Daniel and Martin 2016). ${ }^{4}$ Against this backdrop there is additional research finding that there is an ongoing need for increased and easier access to legal services. In the United States (surprisingly, perhaps), few people seek to resolve disputes legally (Kritzer 2008) and those with low income, as per the study above, face $88 \%$ of their legal issues without a lawyer (Yates et al. 2001, Kritzer 2010).

In Canada and in Ontario, troubling statistics exist, such as the fact that $64 \%$ of familylaw litigants in Canada have no legal representation, or that in any three-year period 12 million Canadians encounter a legal issue, but 20\% take no meaningful legal action to find a solution (Fish 2017, Trabucco 2018). Yet despite this apparent clear need, and the realization that the results of reform are at times unsuccessful, there is little analysis of the relationship between the composition of the legal profession and its impact on access to justice. Similarly, new data increasingly available through the analysis and reporting of practice management firms, has not been included in the analysis and understanding of litigation trends and the relationship between such trends, the legal profession, and public access to the justice system. As data collected by professional firms increasingly reveal, the decision to seek legal representation is a complex one, and relies on many factors, of which cost is but one (Clio 2018). Questions in Canada, and in Ontario specifically, about the state of the legal profession and how it impacts the justice system have been raised from different perspectives, and framed as "access to justice" questions, as "access to the profession" or "articling crisis" questions, as issues of increasing selfrepresentation, and as crises of affordability and efficacy of legal representation.

\footnotetext{
${ }^{3}$ Russia, on the other hand, has seen litigation increase (Titaev 2019). We note as well the methodological challenges of drawing comparisons between jurisdictions as discussed by Onțanu nd Velicogna (2021).

${ }_{4}^{4}$ This methodology can serve as a guidepost for further research in Ontario.
} 
Within the legal profession in Ontario, members have been concerned about the appropriate balance between lawyers and paralegals, in terms of areas of practice, ethical conduct, diversity and overall numbers. Lawyers are less diverse than society at large, and less diverse than paralegals (80\% of lawyers in Ontario identify as white, LSO 2016) but while we and others have criticized barriers that prevent entry into the profession on principled grounds (Levin and Alkoby 2012, Alkoby and Alon-Shenker 2017) there has been little exploration of whether this distinction impacts the justice system in areas such as the propensity for litigation. Similarly, it appears that there are rural and remote geographical areas in Ontario that require a greater number of legal professionals (Baxter and Yoon 2014), but it is not clear whether increasing the number of practicing legal professionals, or changing the ability of existing professionals to practice, will alleviate or effectively address the ability of Ontarians to access the justice system. To note but one counter-intuitive example, research has shown that reforms to Small Claims litigation in Ontario, that were perhaps meant to increase access to this part of the justice system, have not in fact resulted in an overall increase in such litigation (Niblett and Yoon 2017).

Would a larger profession, or one in which paralegals are licensed for more legal work, have a negative or a positive societal and systemic impact in Ontario? That is very much an open question, and overall we find it striking that such debates over the profession in Ontario have largely taken place in an empirical void, and on principled grounds, and that where empirical work does exist (e.g., with respect to small claims litigation postreform) its implications for the justice system have not been considered in policymaking. In our view, an empirical examination of the relationship between the composition of the legal profession and litigation trends in Ontario is essential in order for meaningful progress to occur towards an improved justice system. If such arguments are to be the basis for policy in the Canadian and Ontarian legal landscape, they must be founded on sound empirical research. In the following section we present the beginning of our contribution to this debate.

\section{Findings and discussion}

In this section we present the trends we have been able to observe in the profession and in litigation, and then compare them.

\section{a. The profession}

As could be expected from the concerns voiced about it, the profession in Ontario has indeed grown in absolute numbers over the years. In the early 1980s there were about 15,000 lawyers licenced by the Law Society, whereas in 2017 there were just over 52,000. The number of lawyers has therefore more than tripled in the past forty years. To that number must be added the number of paralegals licenced in the province. Ten years ago there were about 2,300 paralegals licenced in Ontario. That number has almost quadrupled in ten years to 8,700 paralegals in 2017. Together, therefore, there are just over 60,000 licenced members of the legal profession in Ontario.

Absolute numbers must be adjusted, however, for the growth of the population in Ontario. When examining the ratio of licenced lawyers and paralegals to 100,000 people, the following trends are observed: 


\section{CHART 1}

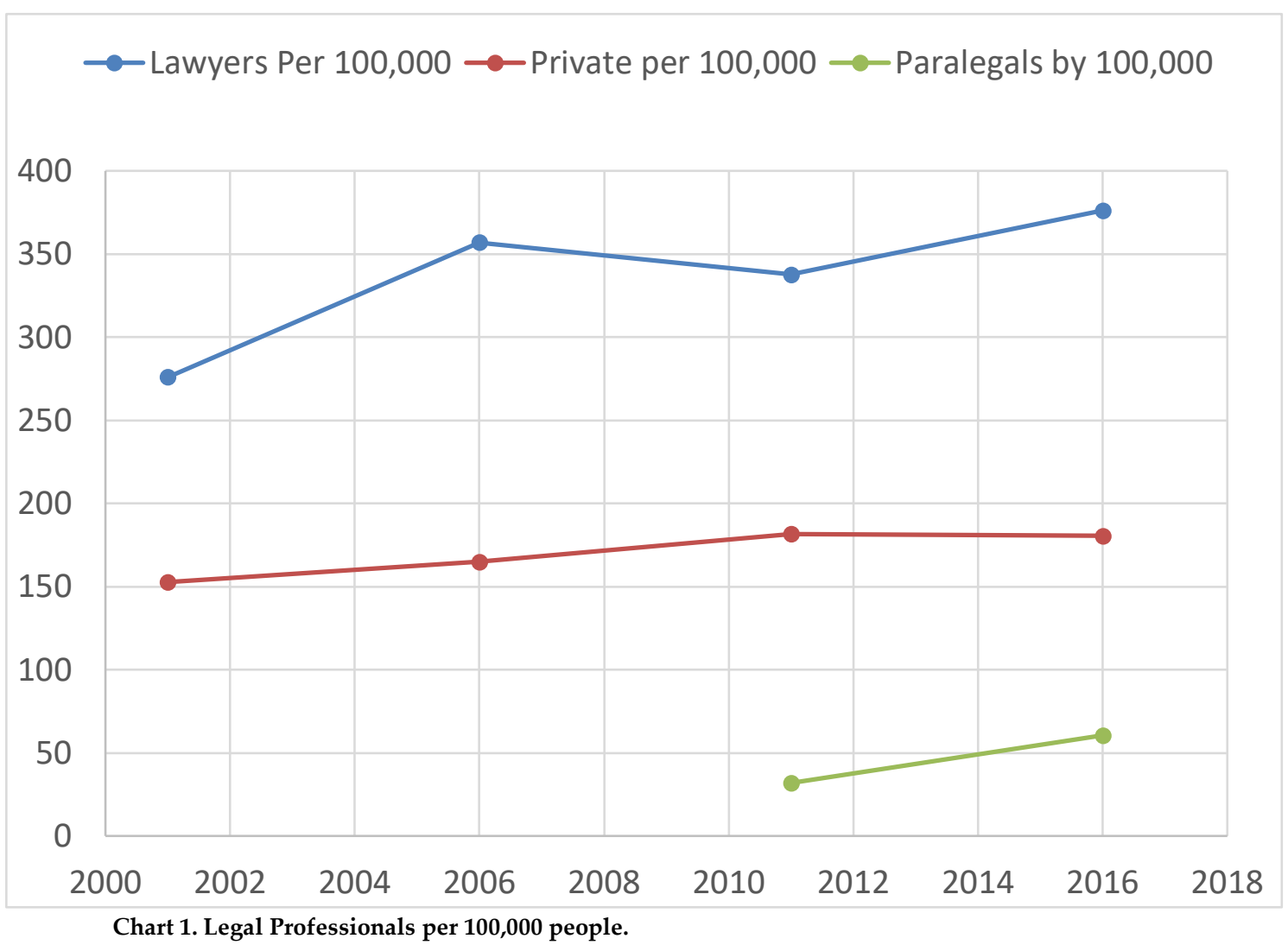

First, it is clear from this chart that the ratio of lawyers to people has gone up, and not only the absolute numbers. The chart captures the last twenty years, but the increase of the ratio has been ongoing since the early 1980s, from about 175 lawyers to 100,000 people to most recently, 375 . The ratio has, in other words, more than doubled in the last forty years, while the absolute number, as noted above, has tripled. Second, the ratio of paralegals to the population has also increased, from about thirty paralegals to 100,000 people ten years ago, to roughly sixty now. The ratio of paralegals to the population has therefore doubled, while their absolute number almost quadrupled. Third, the ratio of lawyers in private practice to the population (i.e., those lawyers most closely associated with the trends in civil litigation that we explore below) has also increased, albeit not as prominently. There were about 150 lawyers in private practice for every 100,000 people in Ontario in the early 1990s, and thirty years later there are about 180 . The ratio has increased, in other words, by twenty percent over that period of time. We discuss below how this relatively modest increase in the number of lawyers who could be working in civil litigation may explain the trends in litigation that we observed.

As mentioned, the LSO has published, for the last twenty years or so, additional information about lawyers and their self-reported areas of practice. Lawyers are asked to report whether they spend some of their time (twenty percent), half their time, or most of their time (eighty percent) on a certain area of practice. This information allows us to inquire in more detail into the number of lawyers working in areas related to civil litigation, and assist us with the analysis of litigation trends. According to the LSO, the number of lawyers devoting at least twenty percent of their time to civil litigation rose from about 7,200 in 2002 to about 9,700 in 2017. As a percentage of the overall number 
of lawyers however, the ratio of lawyers in civil litigation has slightly dropped over the years, from $21.5 \%$ in 2002 to $18.5 \%$ in 2017 . Then again, the number of such lawyers for 100,000 people has increased, from 54 lawyers in 2001 to 72 lawyers in 2017. It may seem therefore, that within the last twenty years lawyers have been moving away from civil litigation, yet that move has not had a large impact on the availability of such lawyers to the general population, thanks to the overall increase in the number of lawyers in general.

A close examination of the data related to lawyers spending half or most of their time in civil litigation, however, reveals a more complex picture. The percentage of lawyers spending at least half of their time on civil litigation out of the total number of lawyers barely changed, from eight percent in 2002 to nine percent in 2017. The percentage of lawyers spending most of their time on civil litigation increased from four percent in 2002 to six percent in 2017. It could be argued, therefore, that the number of lawyers that focus on civil litigation within the profession has increased. This may be, perhaps, due to increased specialization within the profession. The impact on the population in general is captured in the following chart. It can be seen that regardless of the amount of time that lawyers spent on civil litigation, the number of lawyers in civil litigation for 100,000 people has increased over the years.

\section{CHART 2}

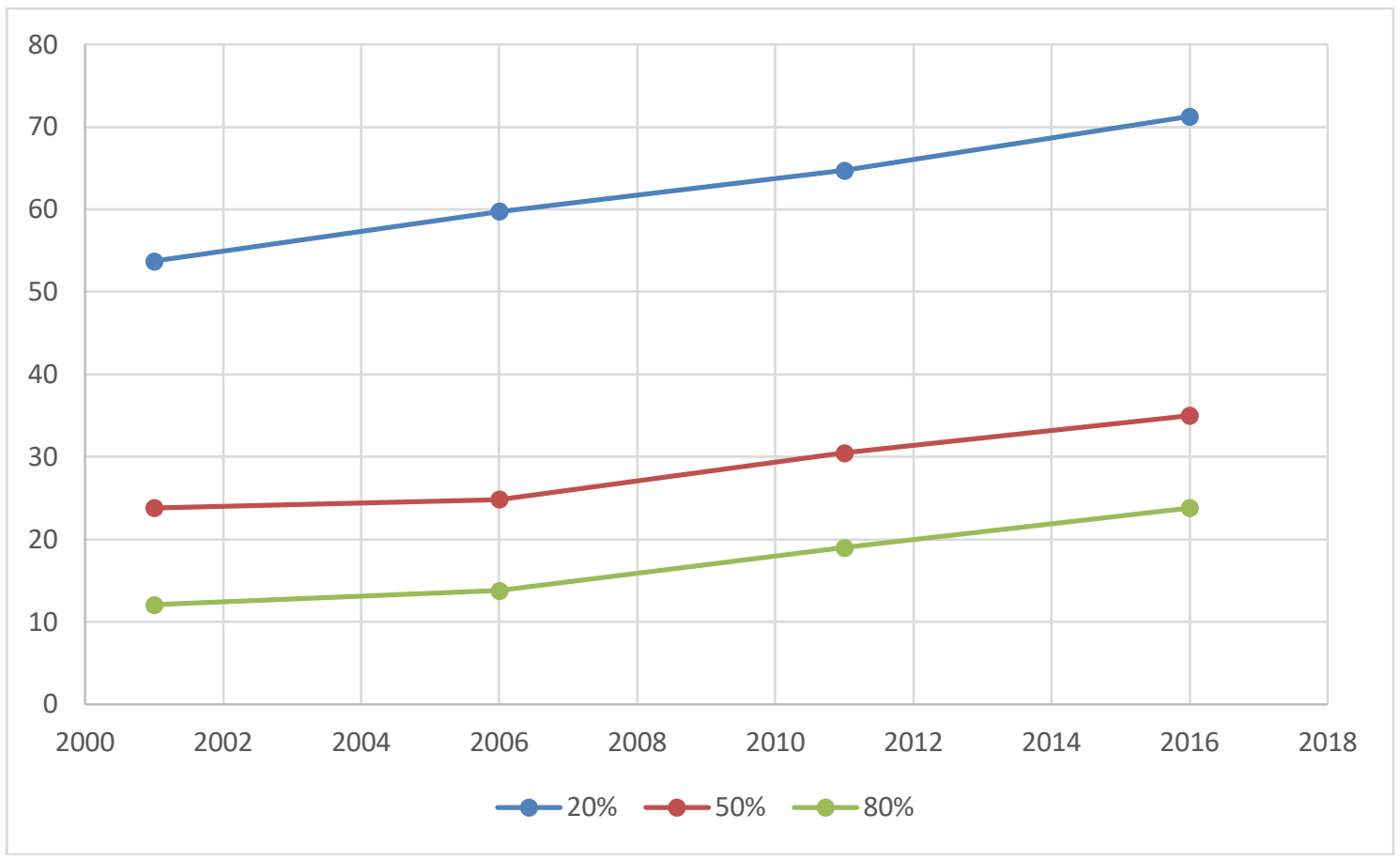

Chart 2. Lawyers in civil litigation per 100,000 people.

Thanks to the information made available by the Law Society similar analyses can be conducted with respect to other areas of practice, but we do not present them here, since there is no corresponding litigation data to compare them with. Anecdotally, however, it is often said that litigation trends are impacted by trends in alternative dispute resolution (for instance, it is claimed that litigation numbers drop with the advent of ADR; we touch on this further in the discussion below). It is therefore worthwhile to inquire about the number of lawyers that have reported to devote their time to ADR. 
According to the LSO, the number of lawyers devoting at least twenty percent of their time to ADR actually dropped from about 350 in 2002 to about 250 in 2017. As a percentage of the overall number of lawyers, the ratio of lawyers in ADR has dropped from $1 \%$ in 2002 to $0.5 \%$ in 2017 . Similar trends present themselves when examining the number of lawyers more focused on ADR. The percentage of lawyers spending at least half of their time on ADR out of the total number of lawyers dropped from $0.6 \%$ to $0.2 \%$ from 2002 to 2017. The percentage of lawyers spending most of their time on ADR dropped from $0.3 \%$ to $0.15 \%$. In other words, regardless of the amount of time they spent on ADR, the number of lawyers in this area of practice out of the total number of lawyers has been halved over the last twenty years.

In the case of ADR practice it seems that the overall increase in the number of lawyers has not been able compensate for this decline. The number of lawyers spending at least some of their time on ADR for one million people has decreased, from 33 lawyers in 2001 to 17 lawyers in 2017. Similar trends exist with respect to the number of lawyers spending half, or most of their time on ADR, as well. The impact on the population in general is captured in the following chart. It can be seen that regardless of how central it is to their practice, fewer lawyers are available in ADR over time.

\section{CHART 3}

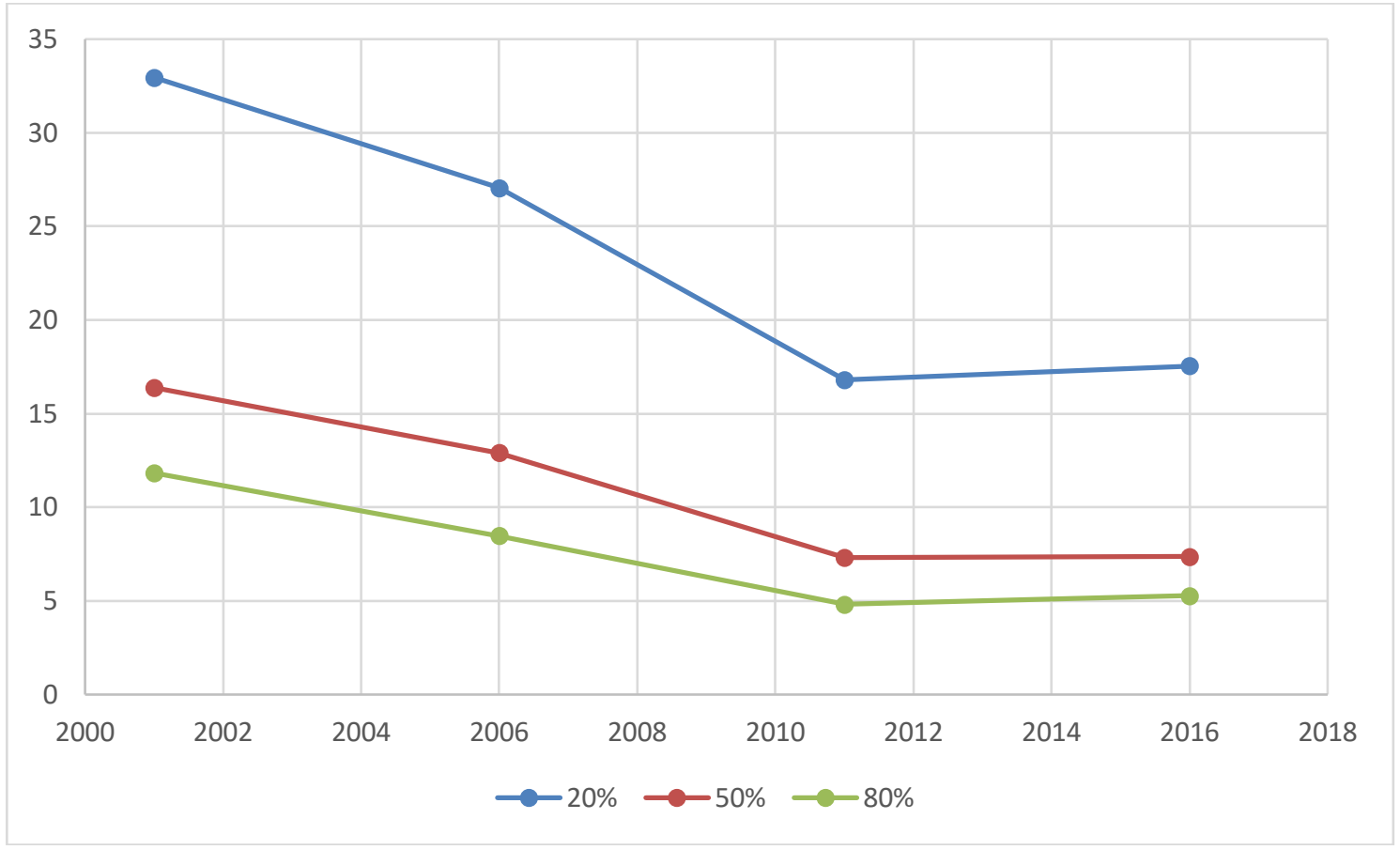

Chart 3. Lawyers in ADR per one million people.

\section{b. Litigation data}

In this section we present the data we have analyzed first, based on the data from Statistics Canada, and second, adding the data from the older Ontario Courts statistics report. This is to ensure that our discussion is not compromised by potential challenges to our method of extrapolating the data earlier than 2006.

The Statistics Canada data for litigation in Ontario indicate that the amount of litigation in the province has largely been the same over the decade between 2006 and 2016, regardless of the type or cause of action. These trends are shown in the following chart. 


\section{CHART 4}

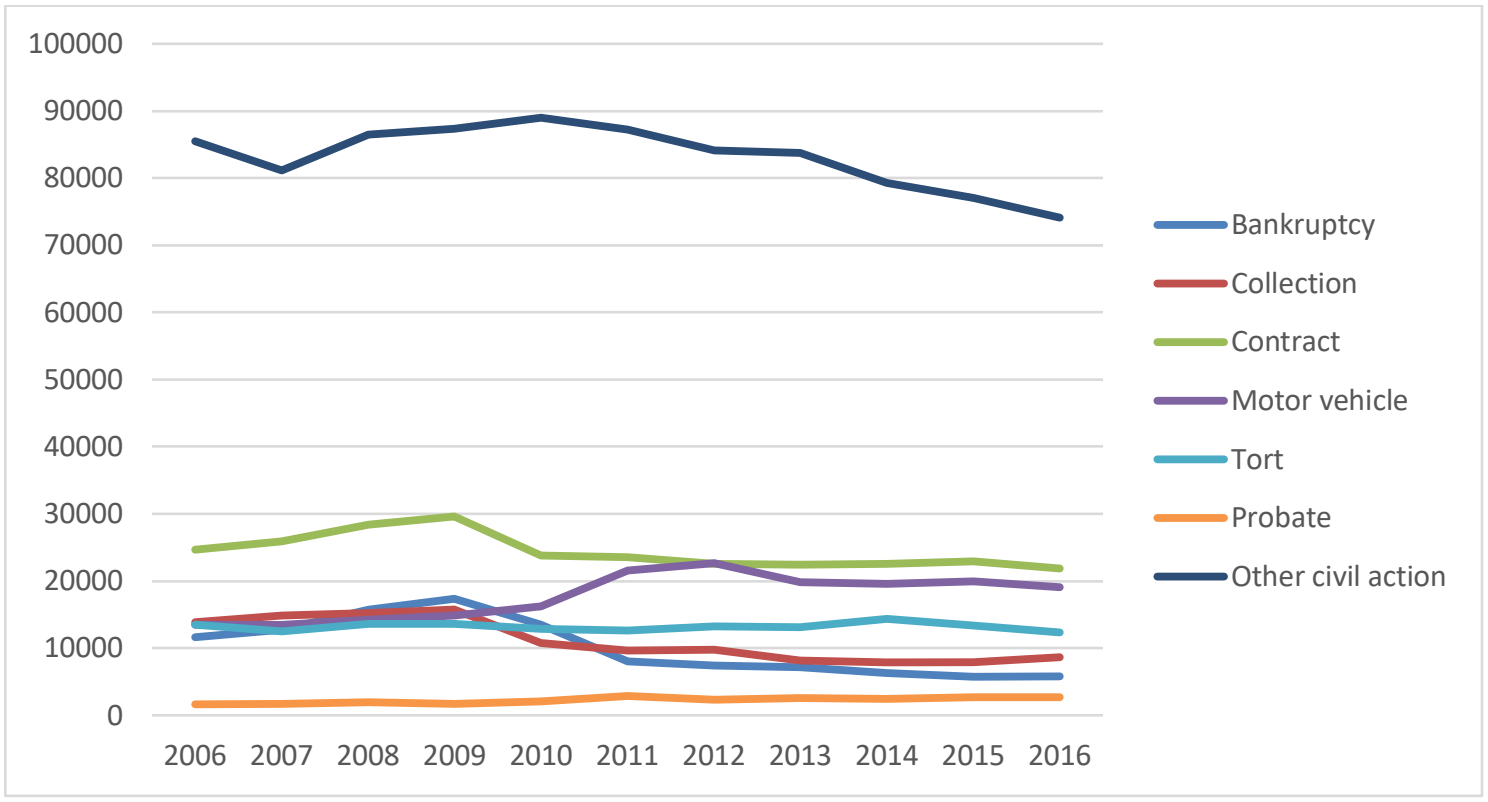

Chart 4. Number of cases (2006-2016).

As could be expected, given these relatively flat graphs, the ratio of the number of cases for 100,000 people has actually declined over the years. This trend is generally similar regardless of cause of action, as shown in the following chart.

\section{CHART 5}

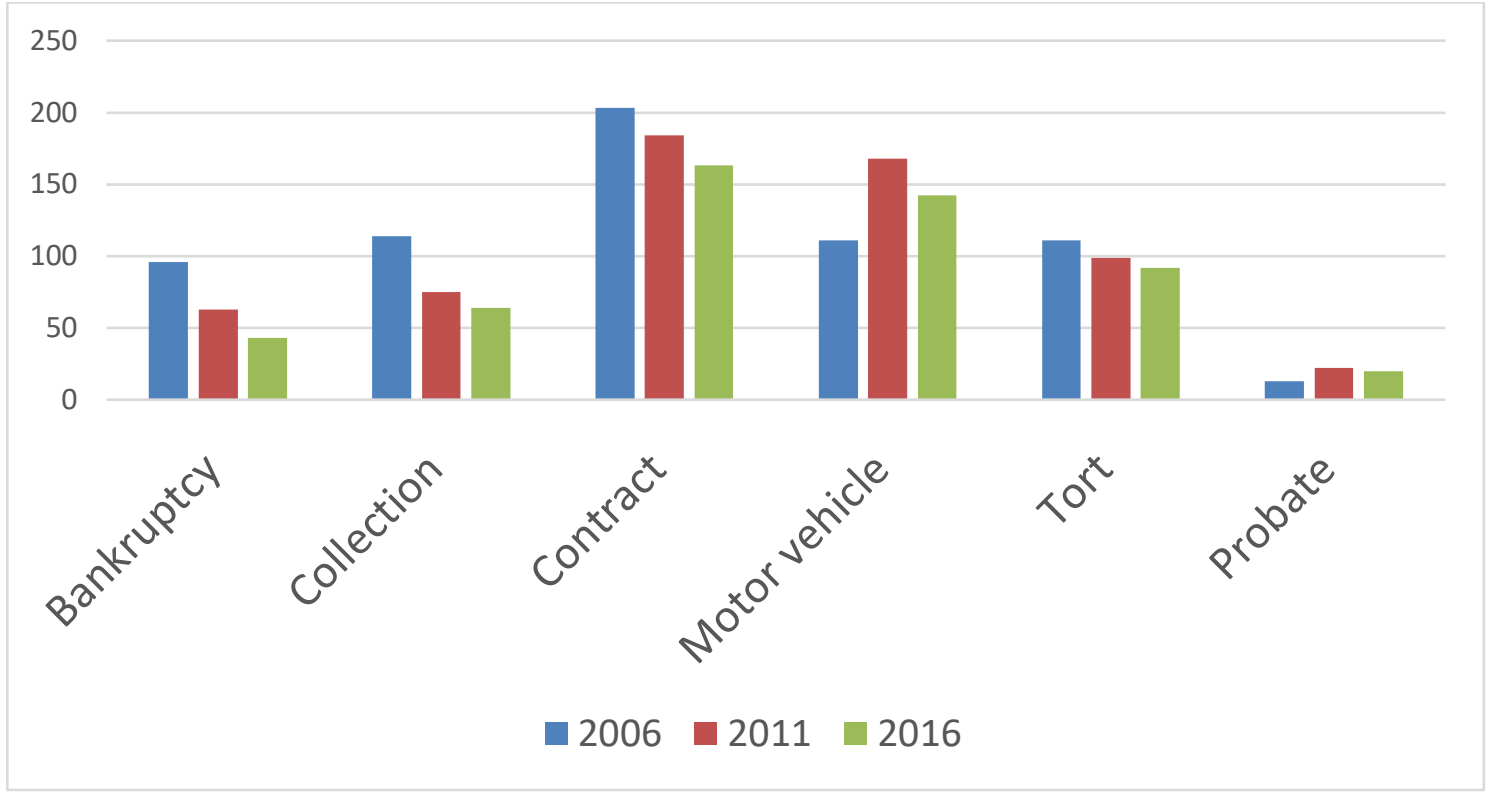

Chart 5. Actions per 100,000 people.

Here indeed is the chart for the total number of cases per 100,000 people, demonstrating the same trend. 


\section{CHART 6}

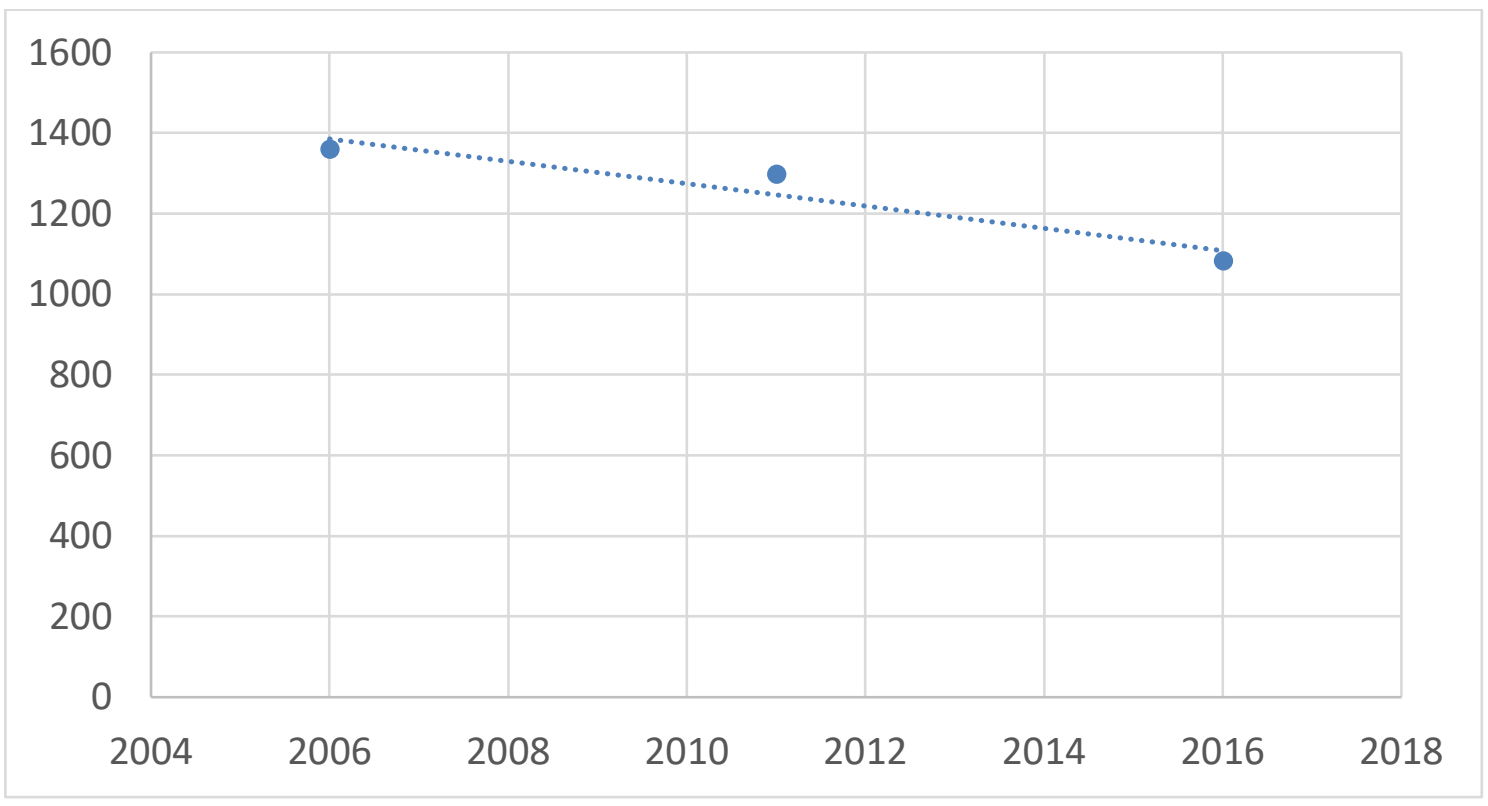

Chart 6. Total cases per 100,000 people (2004-2016).

All three charts lead to the same conclusion. According to Statistics Canada data civil litigation in Ontario has not increased, and has in fact decreased, when compared to the growth of Ontario's population, over the last decade. We compare and discuss this trend with the trend of the number of lawyers in civil litigation over a similar period of time below.

What of the older data? To-date we have been able to extrapolate data from the 1990s. Some categories reported are fairly similar to the Statistics Canada data, such as motor vehicle litigation and probate applications. Others have been grouped together into one big category, which excludes however, as noted above, family law litigation. Broadly speaking, the total number of cases dropped steadily during the 1990s, as can be discerned from the following chart.

\section{CHART 7}

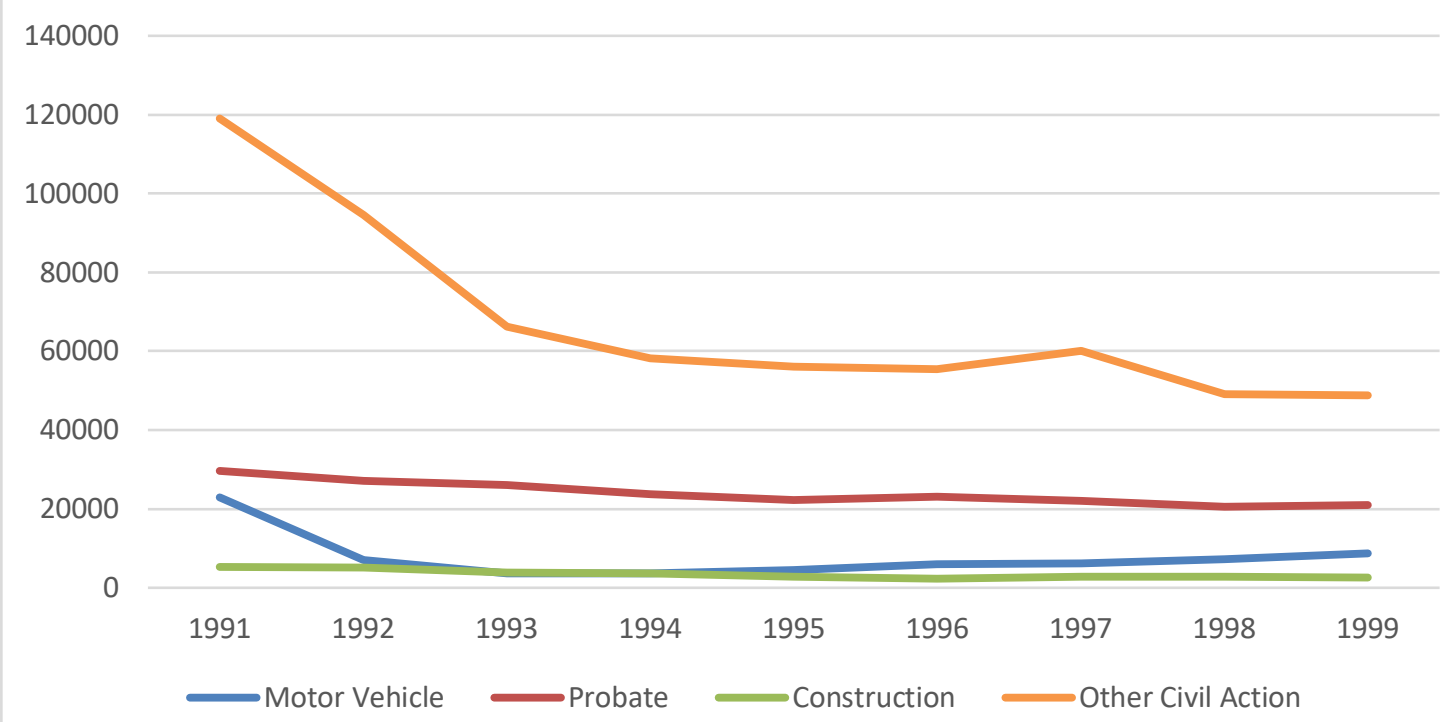

Chart 7. Number of cases (1991-1999). 
As could be expected, this drop resulted in a drop in the ratio of cases to the population, as can be seen in the following chart:

\section{CHART 8}

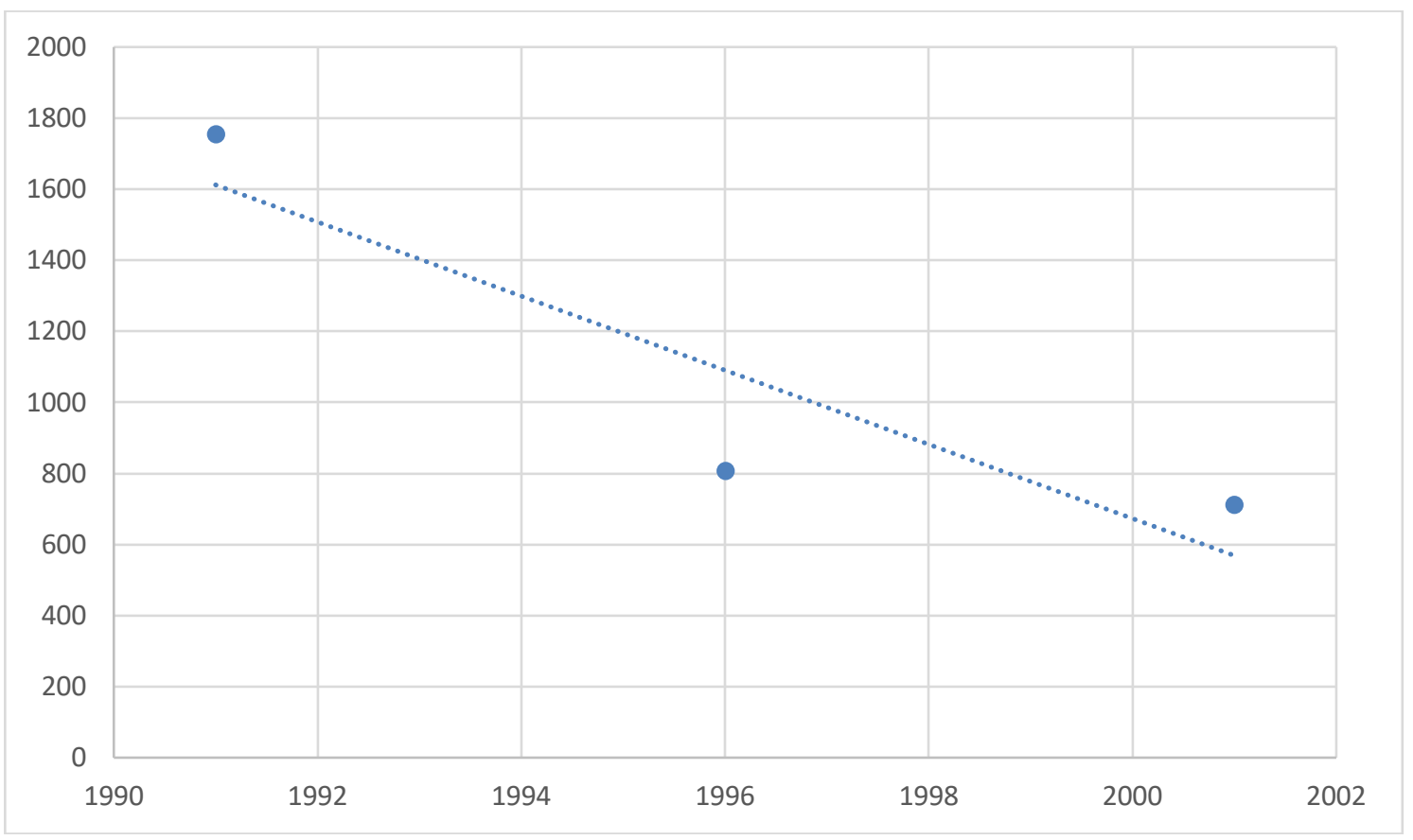

Chart 8. Total cases per 100,000 people (1991-1999).

Attempting to juxtapose the two data sets by comparing ratios indicates the difficulties in extrapolating the data successfully. It seems clear from the following chart that the data points for 1996 and 2001 are lower than would be expected (based on a linear regression).

\section{CHART 9}

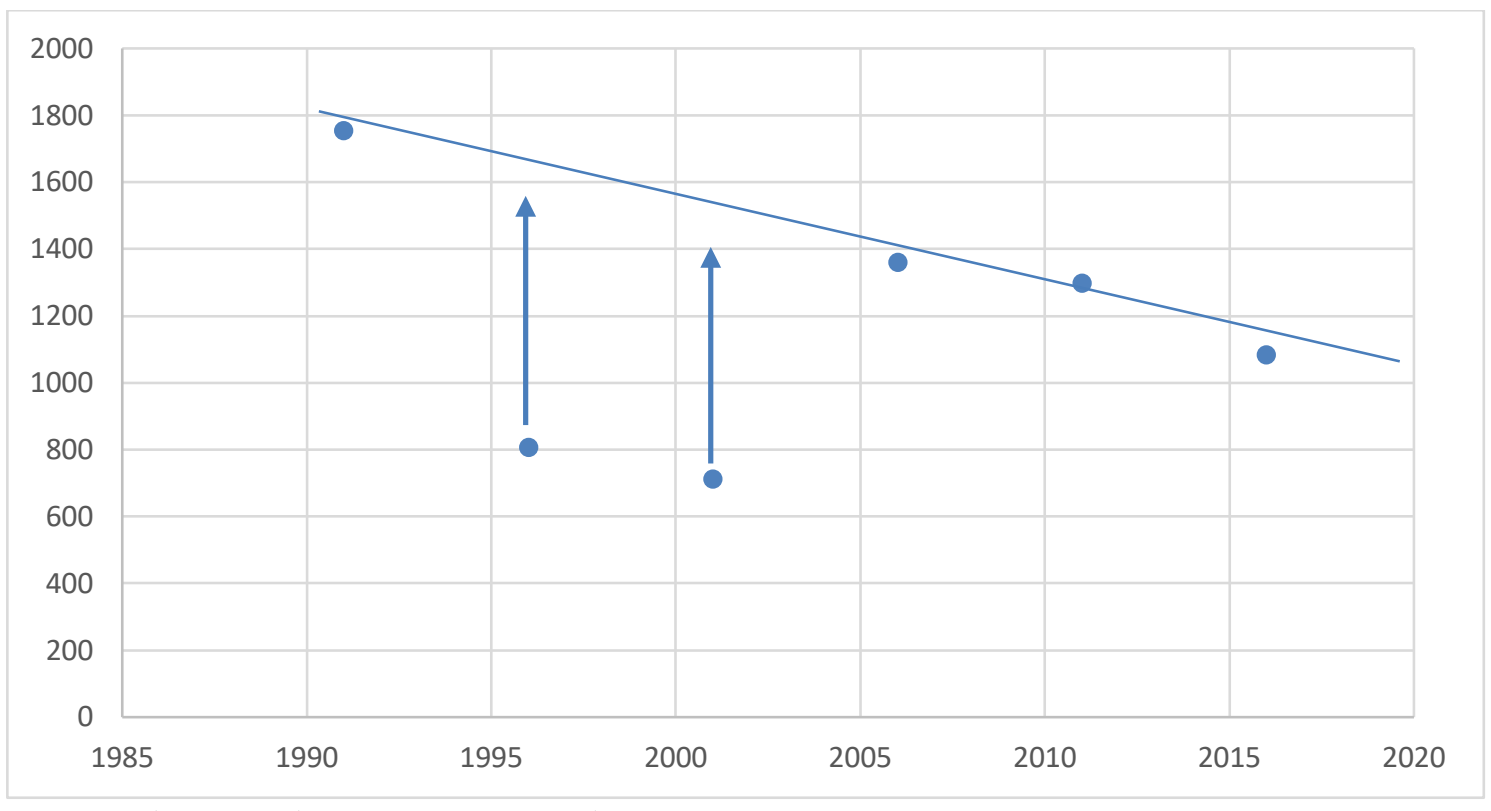

Chart 9. Total cases per 100,000 people.

The Ontario reports note that data were under-reported in 1996, but it is not clear why the data are also low for 2001. 


\section{c. Comparing lawyers and litigation}

Let us now turn to a comparison of the two trends and then to a discussion about their possible causes. We can summarize our observations above regarding the legal profession as follows: The overall number of lawyers, and their ratio with respect to the overall population, have both increased over time. The number of lawyers engaged to some or a greater extent in civil litigation has not shown a consistent trend, yet the ratio of lawyers in the area of civil litigation with respect to the overall population has also increased over time. Finally, the ratio of lawyers engaging in ADR with respect to Ontario's population has not increased and has in fact declined. Ontario, therefore, has more lawyers, and more lawyers available to the general public for civil litigation, but fewer lawyers available for ADR.

On the assumption (or fear) that an increase in the number of lawyers, and specifically in the number of lawyers that practice litigation, will result in an increase in litigation, we would expect to observe, indeed, a similar trend of an increase in the amount of litigation in Ontario over time. However, as discussed in the previous section, civil litigation in Ontario has remained relatively constant in terms of the absolute number of cases that were initiated (regardless of the type of civil action). As a result, due to the increase in population, the ratio of civil cases to the overall population has in fact decreased. This decreasing trend is observed both in the data collected over the last fifteen years by Statistics Canada and in the data collected previously by the Ministry of the Attorney General of Ontario.

Simply put, the number of lawyers in Ontario has gone up, while the number of civil cases in Ontario has gone down. We discuss the positive (for those concerned about litigation explosion) and negative (for those concerned about access to justice) implications of this observation in the following section. First, however, we present it in graphic form. The following chart portrays the absolute numbers of lawyers and cases during the period covered in the Statistics Canada data set.

\section{CHART 10}

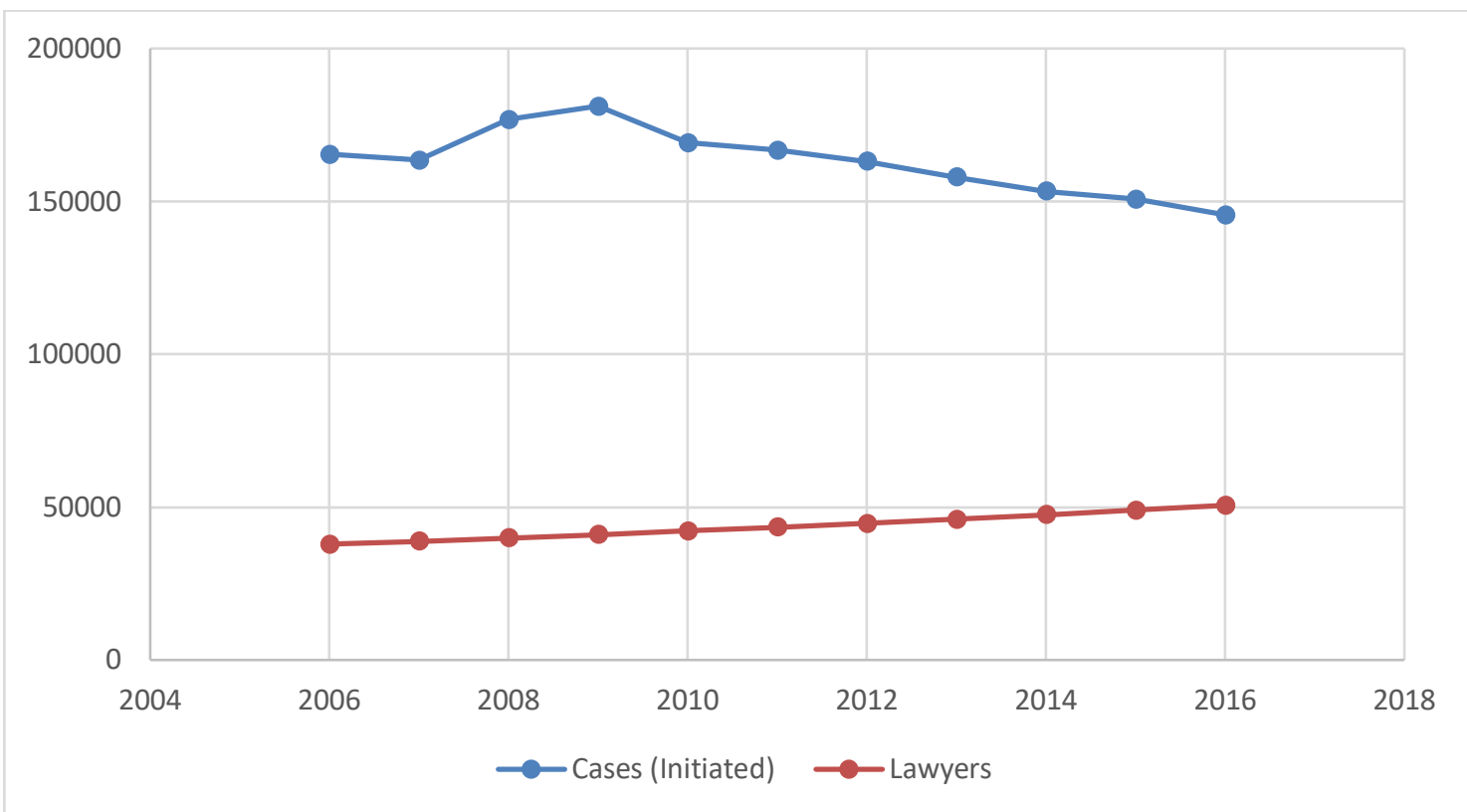

Chart 10. Cases v lawyers. 
Here is the same information with respect to the Ontario government's earlier data.

\section{CHART 11}

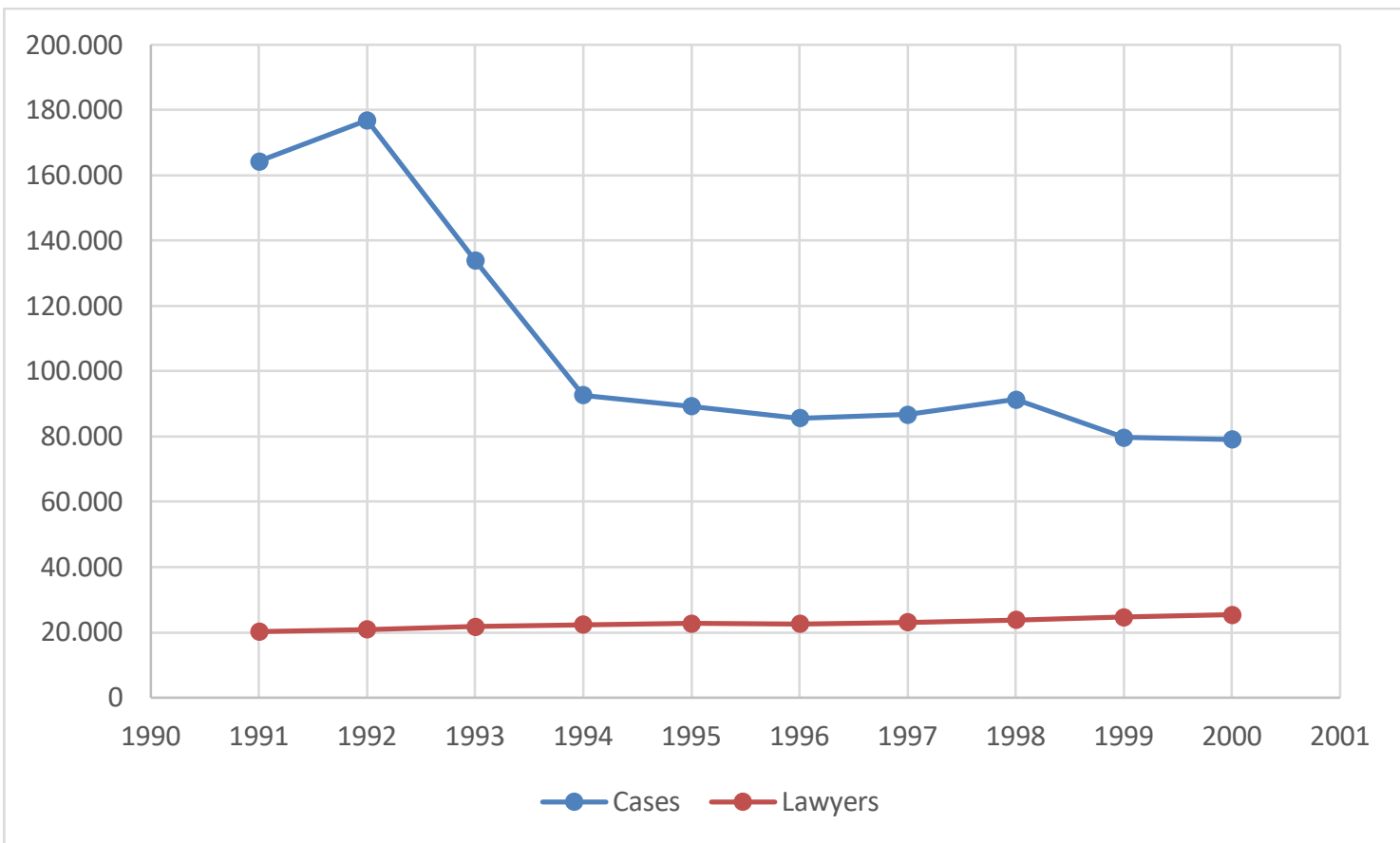

Chart 11. Total cases $v$ total lawyers (1990s).

The following chart presents the ratios with respect to the general population for the period covered by Statistics Canada data.

\section{CHART 12}

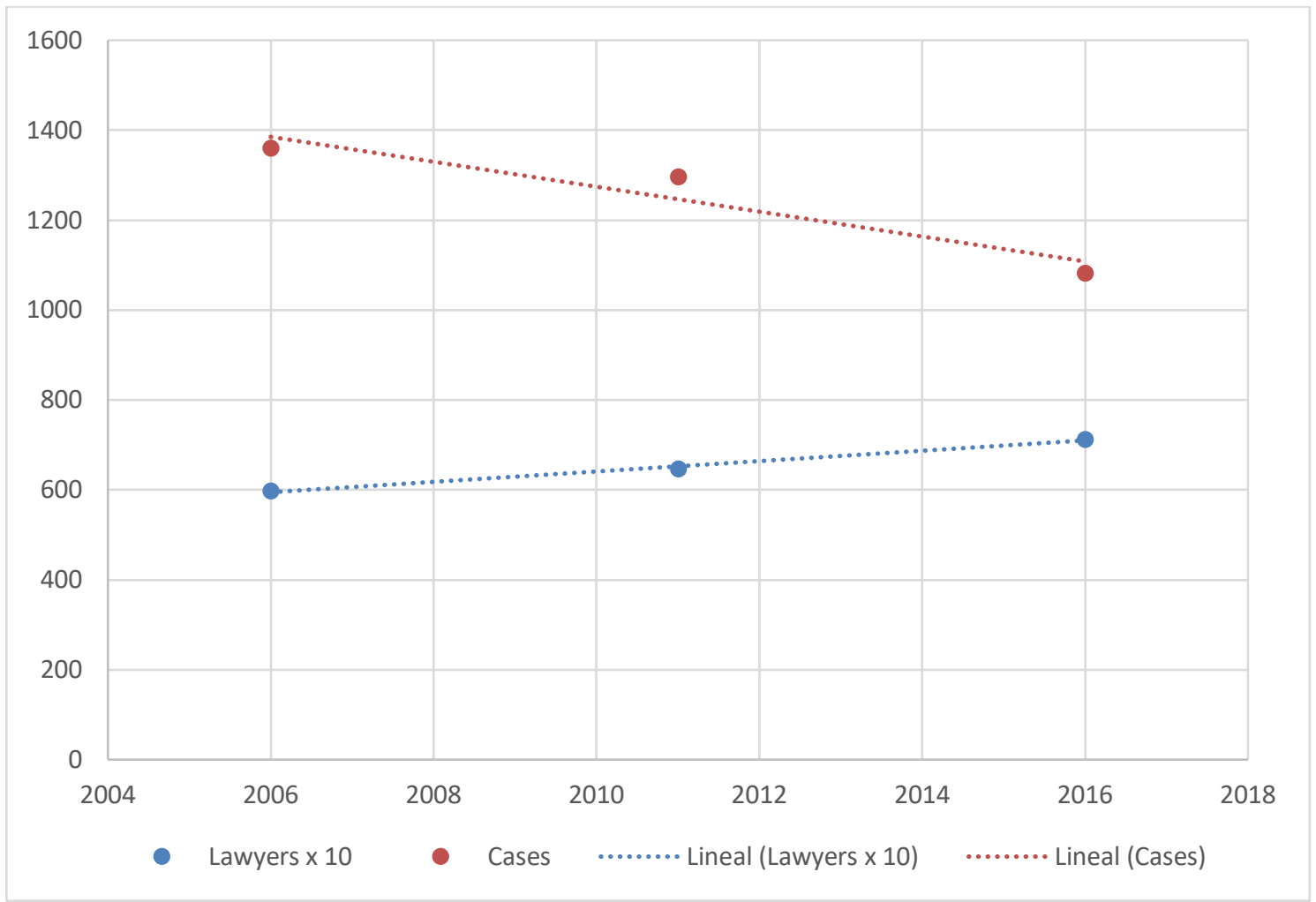

Chart 12. Civil litigation cases v lawyers per 100,000 people. 


\section{Discussion}

What are we to make of the counter-intuitive trend portrayed above? Several points come to mind. Preliminarily, of course, we reiterate that the question of causation for the observed trends remains open, as there could many possible reasons for the trends we have identified. Further, the decision whether or not to litigate is complex and multifaceted, ${ }^{5}$ and cannot be exhaustively understood when examined from only one perspective (see, e.g., Engel 2016). ${ }^{6}$

Among the possible reasons for the specific trends in litigation in Canada and specifically in Ontario, the following are worth highlighting. First are economic reasons. It is possible that the increase in litigation circa 2009 was the result of the global economic crisis of 2008. This crisis may have led to disputes as a result of increasing debt and bankruptcy issues that originated during the crisis and were litigated subsequently. ${ }^{7}$ Second, the relationship between litigant and legal system may be a specific example of a more general relationship between a member of society and social institutions. Research on emerging economies highlights reasons that generally impede the development of social institutions and that could lead in other jurisdictions to a lack of trust in the legal system, a cultural-religious sense that litigation is not "appropriate", and movement toward ADR (Nichols 2003). Third, it is possible that more legal relationships are structured as to eliminate litigation as a form of dispute resolution, in favour of arbitration. Arbitration clauses are particularly prevalent in contracts of adhesion and other situations where one party has greater economic clout and is typically a corporation managing its commercial relations with individual customers. Fourth, and specific to Ontario, it is possible that legal system reforms and specifically of the small claims system have not led to an increase in litigation as originally expected. Fifth, legal firm partnership data from Ontario, and, in particular, a decline in new equity partners, may suggest that litigation generates less profit than could be expected, and as a result that firms have discouraged clients from litigating. ${ }^{8}$

Further research is required on all of the above, but before touching upon potential directions of research in the concluding section, two additional points are worth noting. We are careful to limit our discussion, in making them, to the more recent data (not subject to our extrapolation) collected by Statistics Canada. First, concerns that an increase in the number of lawyers will lead to an increase in litigation are misguided and misleading. The number of lawyers in Ontario has increased steadily over time, and the number of lawyers focusing on civil litigation has also increased over time. Despite these increases there has been no corresponding increase in litigation. In absolute numbers litigation has not increased, and when adjusted for the growth of Ontario's population it has in fact decreased. So it may be somewhat of a bold conclusion, but we would suggest that, as we have learnt from the other papers in this issue, that in many

\footnotetext{
${ }^{5}$ And in the extreme case of querulants, pathological (Katvan and Shnoor 2021).

${ }^{6}$ Even in criminal prosecution, when decisions are made supposedly by the same party (the state), research demonstrates the complexity of the factors that have an impact upon criminal litigation trends (Ostrom 2019); even humour appears to be a relevant factor (Roach-Anleu and Mack 2019).

${ }^{7}$ However, the early 1990s saw an economic recession as well, albeit not of the magnitude of the 2008 crisis, yet litigation dropped in those years and has not increased since.

${ }^{8}$ We thank participants in the 2019 conference of the Canadian Academy of Legal Studies in Business for their discussion of these points.
} 
jurisdictions an increase in lawyers does not in fact result (or at least not necessarily result) in an increase in litigation. On the contrary, Germany, Japan, the Netherlands, the United Kingdom and the United States have all seen a decrease in litigation (Yates et al. 2001, Kritzer 2004, Chan 2019, de Groot-van Leeuwen 2019, Schultz 2019, Seidman 2021, Bocharov 2021). "Litigation explosion" is a myth, and as noted by Engel, Galanter and others the diminishing of litigation is a more pressing concern (Galanter 2004, Engel 2016). ${ }^{9}$ More lawyers do not bring about more litigation.

Second, however, it is equally apparent that more lawyers do not bring about greater access to justice, (or to the legal system). While allowing for more lawyers may allow for a larger and potentially more diverse profession that is more representative of the general population, such an increase does not bring with it greater access to the justice system. We have seen above that even when thought of in a broader sense, as encompassing ADR, that the increase in the overall number of lawyers has not led to increased ADR practice. This despite the potential explanatory force of arbitration clauses as a reason for the lack of increase in litigation that we mentioned above. Indeed, such use of ADR has led some champions of ADR to go so far as to conclude that ADR has failed to provide access to justice, and that more litigation is required (MenkelMeadow 2021). From this perspective, there has been an insufficient increase in litigation and a failure of several legal systems to provide members of society with appropriate access to justice.

\section{Conclusion}

Both of these last points, essentially two sides of the same coin, indicate that understanding how to improve access to the justice system will require more data than is to be found in counting lawyers and cases. However, counting lawyers and cases in Ontario has helped us to definitively put to rest the concern that Ontario is suffering from problems of too much litigation and from too many lawyers. More lawyers are not bad for society, and more litigation is not to be dreaded, as long as these increases reflect the diversity of society and result in greater numbers of Ontarians accessing the justice system. We conclude that there is not too much litigation in Ontario, and that we now need to understand why an increase in the legal profession has not resulted in a more accessible justice system.

On the basis of this conclusion future research can now proceed in several directions. Our hope is that interested scholars will continue to explore law as a social institution and to explore trust-generating factors, in order to ultimately understand how to increase trust in the legal system. Others may wish to compare civil and criminal litigation to determine whether models used to explore criminal litigation trends can be useful for civil litigation as well.

We plan to add to the debate by obtaining data from practice-management firms in the hope that it will shed light on the internal factors that impact issues such as individual self-representation, the efficiency of law firms, the relationship between small and medium businesses and the legal profession, and the business of law, to name but a few. By examining such factors we hope to contribute from an empirical basis to the

\footnotetext{
${ }^{9}$ Our thanks to Lynn Mather and Avrom Sherr for directing us to these sources.
} 
international, ongoing, professional and academic debate on how legal systems generally, and in Ontario specifically, will be able to deliver greater access to justice.

\section{References}

Abel, R.L., 1988. The contradictions of professionalism. In: R.L. Abel and P.S.C. Lewis, eds., Lawyers in Society. Vol. 1, The Common Law World. Berkeley: University of California Press, 186-243.

Alexander, R., 1994. Before you believe in a litigation explosion. The New York Times, 8 April.

Alkoby, A., and Alon-Shenker, P., 2017. Out of the Closet and Up the Ladder?

Diversity in Ontario's Big Law Firms. Windsor Yearbook of Access to Justice, 34(2), 40-72.

Andrew, E., Robson, J., and Lippert, O., 1999. Law and markets: Is Canada inheriting America's litigious legacy? Journal of Canadian Studies, 34(1), 184-200.

Baxter, J., and Yoon, A., 2014. No lawyer for a hundred miles? Mapping the new geography of access of justice in Canada. Osgoode Hall Law Journal [online], 52, 9 57. Available from: http://digitalcommons.osgoode.yorku.ca/ohlj/vol52/iss1/1 [Accessed 15 January 2020].

Bielenand, S., and Marneffe, W., 2018. Testing the Lawyer-Induced Litigation Hypothesis in Europe. Applied Economics [online], 50(16). Available from: https://doi.org/10.1080/00036846.2017.1374544 [Accessed 15 January 2020].

Bocharov, T., 2021. Is there a "compensation culture" in contemporary Russia? The role of liability insurance, non-pecuniary damages, and legal profession in personal injury litigation. Oñati Socio-Legal Series [online], 11(2-this issue). Available from: https://doi.org/10.35295/osls.iisl/0000-0000-0000-1141 [Accessed 9 March 2021].

Burns, R.P., 2013. Advocacy in the Era of the Vanishing Trial. Kansas Law Review [online], vol. 61, 893. Available from:

https://www.scholars.northwestern.edu/en/publications/advocacy-in-the-era-ofthe-vanishing-trial [Accessed 15 January 2020].

Chan, K.W., 2019. Japanese Litigants after the Justice System Reform: Unreluctant or Still Reluctant? Paper presented at the "Too Much Litigation?" workshop. Oñati International Institute for the Sociology of Law, 27-28 June.

Clio, 2018. Legal Trends Report [online]. Burnaby: Clio. Available from: https://www.clio.com/resources/legal-trends/2018-report/ [Accessed 15 January 2020].

Daniel, S., and Martin, J., 2016. Where Have All the Cases Gone? The Strange Success of Tort Reform Revisited. Emory Law Journal [online], 65(6), 1445. Available from: http://law.emory.edu/elj/content/volume-65/issue-6/articles-essays/where-casesgone-success-tort-reform-revisited.html [Accessed 15 January 2020].

de Groot-van Leeuwen, L., 2019. Too little litigation. Paper presented at the "Too Much Litigation?" workshop. Oñati International Institute for the Sociology of Law, 2728 June. 
Easton, S., 1997. Some economics of the Canadian legal profession. In: J. Robson and O. Lippert, eds., Law and Markets: Is Canada Inheriting America's Litigious Legacy? Vancouver: The Fraser Institute, 75-86.

Engel, D., 2016. The Myth of the Litigious Society: Why We Don't Sue [online]. Chicago University Press. Available from: https://doi.org/10.7208/chicago/9780226305189.001.0001 [Accessed 15 January 2020].

Fish, D., 2017. Are there too many lawyers? PrecedentJD [online], 6 September. Available from: http://precedentjd.com/news/are-there-too-many-lawyers/ [Accessed 15 January 2020].

Galanter, M., 1986. The day after the litigation explosion. Maryland Law Review [online], 46(1), 3-39. Available from:

https://digitalcommons.law.umaryland.edu/mlr/vol46/iss1/4/ [Accessed 15 January 2020].

Galanter, M., 1996. Real World Torts: An Antidote to Anecdote. Maryland Law Review [online], 55(4), 1093-1095. Available from: https://core.ac.uk/download/pdf/56358099.pdf [Accessed 15 January 2020].

Galanter, M., 2004. The Vanishing Trial: An Examination of Trials and Related Matters in Federal and State Courts. Journal of Empirical Legal Studies [online], 1(3), 459570. Available from: https://doi.org/10.1111/j.1740-1461.2004.00014.x [Accessed 15 January 2020].

Gonzalez, G., 2006. Rising litigation trends increase demand for E\&O coverage in Canada; Legal changes ease filing of class actions in several jurisdictions. Business Insurance, 40(44), 27.

Harnick, C., 1997. Civil justice reform in Ontario. In: J. Robson and O. Lippert, eds., Law and Markets: Is Canada inheriting America's Litigious Legacy? Vancouver: The Fraser Institute, 109-114.

Katvan, E., 2013. "Overcrowding the profession" - An artificial argument? Oñati SocioLegal Series [online], 3(3), 409-429. Available from: http://opo.iisj.net/index.php/osls/article/viewFile/207/250 [Accessed 15 January 2020].

Katvan, E., and Shnoor, B., 2021. Don Quixote de la Corte: Serial litigants, emotions, and access to justice. Oñati Socio-Legal Series [online], 11(2-this issue). Available from: https://doi.org/10.35295/osls.iisl/0000-0000-0000-1117 [Accessed 9 March 2021].

Kritzer, H.M., 2004. Disappearing trials - A comparative perspective. Journal of Empirical Legal Studies [online], 1(3), 735-754. Available from: https://doi.org/10.1111/j.1740-1461.2004.00022.x [Accessed 15 January 2020].

Kritzer, H.M., 2008. To lawyer or not to lawyer: Is that the question? Journal of Empirical Legal Studies [online], 5(4), 875-906. Available from: https://doi.org/10.1111/j.17401461.2008.00144.x [Accessed 15 January 2020]. 
Kritzer, H.M., 2010. Examining the real demand for legal services. Fordham Urban Law Journal, 37(1), 255-272.

Law Society of Upper Canada (LSO), 2016. Annual Report Data. Law Society of Upper Canada: 2016 annual report [online], p. 50. Available from:

http://annualreport.lsuc.on.ca/2016/en/annual-report-data.html [Accessed 15 January 2020].

Law Society of Upper Canada (LSO), 2017. Law Society benchers approve action plan to improve access to justice for families via special licensing for paralegals and others [online]. Press release. 1 December. Available from: https://lso.ca/newsevents/latest-news/latest-news-2017/law-society-benchers-approve-action-planto-improve-access-to-justice-for-families-via-special-licen [Accessed 15 January 2020].

Levin, A., and Alkoby, A., 2012. Is Access to the Profession Access to Justice? Lessons from Canada. International Journal of the Legal Profession [online], 19(2-3), 283-299. Available from: https://doi.org/10.1080/09695958.2013.771123 [Accessed 15 January 2020].

Menkel-Meadow, C., 2021. What is an appropriate measure of litigation?

Quantification, qualification and differentiation of dispute resolution. Oñati SocioLegal Series [online], 11(2-this issue). Available from: https://doi.org/10.35295/osls.iisl/0000-0000-0000-1146 [Accessed 9 March 2021].

Niblett, A., and Yoon, A.H., 2017. Unintended consequences: The regressive effects of increased access to courts. Journal of Empirical Legal Studies [online], 14(1), 5-30. Available from: https://doi.org/10.1111/jels.12140 [Accessed 15 January 2020].

Nichols, P., 2003. Trust in Institutions in Kazakhstan. Central Asian Journal of Management, Economics and Social Research, 3, 159-172.

Nockleby, J.E., 2007. How to Manufacture a Crisis: Evaluating Empirical Claims Behind “Tort Reform”. Oregon Law Review, 86, 553-554.

Olson, W., 1997. How America got its litigation explosion: Why Canada should not consider itself immune. In: J. Robson and O. Lippert, eds., Law and Markets: Is Canada Inheriting America's Litigious Legacy? Vancouver: The Fraser Institute, pp. 21-26.

Onțanu, E., and Velicogna, M., 2021. The challenge of comparing EU Member States judicial data. Oñati Socio-Legal Series [online], 11(2-this issue). Available from: https://doi.org/10.35295/osls.iisl/0000-0000-0000-1151 [Accessed 9 March 2021].

Ostrom, B., 2019. Under Pressure: How Courts Control the Volume of Criminal Litigation using Differentiation, Dismissal, and Delay. Paper presented at the "Too Much Litigation?" workshop. Oñati International Institute for the Sociology of Law, 2728 June.

Roach Anleu, S., and Mack, K., 2019. Too much case processing, too little case resolution: Judicial strategies for moving cases along to finalisation. Paper presented at the "Too Much Litigation?" workshop. Oñati International Institute for the Sociology of Law, 27-28 June. 
Scallen, E.A., 2017. In a World of Vanishing Trials: Why the Evidence Course Matters More than Ever - and could Matter Even More. The Review of Litigation, 36(3), 513-527.

Schultz, U., 2019. Coordinates of the delivery of justice in Germany. Paper presented at the "Too Much Litigation?" workshop. Oñati International Institute for the Sociology of Law, 27-28 June.

Seidman, G., 2021. A hard look at common law administrative tribunals. Oñati SocioLegal Series [online], 11(2-this issue). Available from: https://doi.org/10.35295/osls.iisl/0000-0000-0000-1150 [Accessed 9 March 2021].

Solomon, J. M., 2014. Juries, Social Norms, and Civil Justice. Alabama Law Review [online], 65(5), 1125-1128. Available from:

https://www.law.ua.edu/resources/pubs/lrarticles/Volume\%2065\%20Issue\%205/Is sue\%205/Solomon_1125-1203.pdf [Accessed 15 January 2020].

Statistics Canada, 2018. General civil court cases, by type of action, Canada and selected provinces and territories [online]. Data set. 28 November. Available from: https://doi.org/10.25318/3510011401-eng [Accessed 15 January 2020].

The Ottawa Citizen, 1996. Law of oversupply: Canada's lawyers make sound proposals for reforming civil law while missing one problem - too many lawyers. The Ottawa Citizen, 29 August.

Titaev, K., 2019. Too Many Claims in Russia: mobilization of law or dysfunction of the state agencies. Paper presented at the "Too Much Litigation?" workshop. Oñati International Institute for the Sociology of Law, 27-28 June.

Trabucco, L., 2018. What are we waiting for? It's time to regulate paralegals in Canada. Windsor Yearbook of Access to Justice [online], vol. 35, 149-176. Available from: https://doi.org/10.22329/wyaj.v35i0.5277 [Accessed 15 January 2020].

Yates, J., Davis, B.C., and Glick, H.R., 2001. The Politics of Torts: Explaining Litigation Rates in the American States. State Politics \& Policy Quarterly [online], 1(2), 127143. Available from: https://doi.org/10.1177/153244000100100201 [Accessed 15 January 2020].

Yates, J., Tankersley, H., and Brace, P., 2010. Assessing the Impact of State Judicial Structures on Citizen Litigiousness. Political Research Quarterly [online], 63, 796810. Available from: https://doi.org/10.1177/1065912909336271 [Accessed 15 January 2020].

Ziv, N., 2008. Who moved my gown? On the unauthorized practice of Law. Mehkarei Mishpat, 24(2), 439-489. 